\title{
Formulasi dan Evaluasi Gel Antioksidan Ekstrak Daun Bidara (Ziziphus jujuba Mill.)
}

\section{Formulation and Evaluation of Antioxidant Gel Formulated from Jujube (Ziziphus jujuba Mill.) Leaves Extract}

\author{
Trie Yuni Elfasyari ${ }^{*}$, Lita Riastienanda Putri, Sawitri Wulandari \\ Bachelor of Pharmacy Program Study, Mitra Bunda Persada College of Health Sciences, \\ Jl. Seraya, Batam, Kepulauan Riau 24999, Indonesia \\ *Corresponding author email: trieelfasyari@gmail.com
}

Received 3-10-2019

Accepted 25-11-2019

Available online 30-12-2019

\begin{abstract}
ABSTRAK
Daun bidara memiliki kandungan fenolat dan flavonoid yang berkhasiat sebagai antioksidan. Penelitian ini bertujuan untuk memformulasikan ekstrak etanol daun bidara dalam bentuk sediaan gel serta uji aktivitas antioksidannya. Basis gel dibuat dengan variasi konsentrasi HPMC 3, 5, dan 7\% dengan konsentrasi ekstrak 2,5\% untuk setiap formula. Selanjutnya dilakukan evaluasi kestabilan gel selama 3 minggu. Aktivitas antioksidan diuji dengan metode DPPH. Hasil menunjukkan ekstrak etanol daun bidara dapat diformulasikan menjadi sediaan gel antioksidan dengan variasi basis HPMC 3 dan $5 \%$, dimana sediaannya memiliki sifat fisik dan stabilitas yang baik, terbukti dengan tidak adanya perubahan organoleptis, $\mathrm{pH}$, viskositas, dan daya sebar selama evaluasi. Gel ekstrak etanol daun bidara memiliki aktivitas antioksidan yang berbeda-beda berdasarkan variasi konsentrasi HPMC. Peningkatan konsentrasi HPMC menyebabkan perbedaan kemampuan pelepasan zat aktif yang ditunjukkan dengan persen inhibisi yang berbeda untuk $F 1$, $F 2$, and $F 3$ yaitu masing-masing sebesar 52,$55 ; 48,66$; dan $32,88 \%$.
\end{abstract}

Kata kunci: aktivitas antioksidan, daun bidara, gel, HPMC.

\begin{abstract}
Bidara leaves contain phenolics and flavonoids which have antioxidant properties. This study aims to formulate bidara leaf ethanol extract in gel dosage form and test for its antioxidant activity. Gel base is made with variations in the concentration of HPMC 3, 5, and $7 \%$ with extract concentration of $2.5 \%$ for each formula. Then the gel stability was evaluated for 3 weeks. Antioxidant activity was tested by the DPPH method. The results showed ethanol extract of bidara leaves can be formulated into antioxidant gel preparations with a variation of 3 and 5\% HPMC base, where the sedian has good physical properties and stability, as evidenced by the absence of changes in organoleptic,
\end{abstract}


$\mathrm{pH}$, viscosity, and dispersal during evaluation. Bidara leaf ethanol extract gel has different antioxidant activity based on variations in HPMC concentration. Increasing the concentration of HPMC causes differences in the ability to release active substances as indicated by different percent inhibition $\mathrm{F} 1=52.55 \%, \mathrm{~F} 2=48.66 \%$, and $\mathrm{F} 3=32.88 \%$.

Key words: antioxidant activity, jujube leaves, gel, HPMC.

\section{Pendahuluan}

Bidara (Ziziphus mauritiana Lam) adalah salah satu tanaman yang berpotensi sebagai antioksidan alami. Bidara memiliki kandungan fenolat dan flavonoid yang berkhasiat sebagai antioksidan, antiinflamasi, antimikroba, antifungi dan menghambat pertumbuhan tumor (Abalaka et al., 2011; Kaur et al., 2015). Penggunaan secara topikal dalam bentuk gel belum begitu dikenal secara luas oleh masyarakat.

Telah dilakukan penelitian yang menunjukkan bahwa ekstrak etanol dan metanol daun bidara memiliki aktivitas antioksidan dengan IC50 berturut-turut

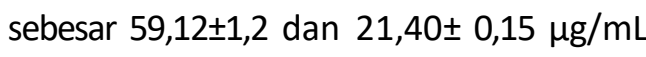
(Samirana et al., 2018; Perumal et al., 2012).

Gel merupakan suatu sediaan semipadat yang jernih, tembus cahaya, dan mengandung zat aktif yang pergerakan medium pendispersinya terbatas oleh suatu jalinan jaringan tiga dimensi dari partikel-partikel atau makromolekul yang terlarut pada fase pendispersi (Ansel, 1989). Ada berbagai macam basis gel yang dapat digunakan, baik dari alam, semi sintetik, maupun sintetis. Hidroksipropil metilselulosa (HPMC) adalah salah satu polimer semi sintetis. HPMC termasuk derivat selulosa yang merupakan eter propilen glikol dari metilselulosa (Depkes RI, 1995).
Dibandingkan basis gel yang lain, HPMC dapat memberikan stabilitas kekentalan yang baik pada suhu ruang, walaupun disimpan pada jangka waktu yang lama. Selain itu HPMC merupakan bahan yang tidak beracun dan noniritatif (Rowe et al., 2009). Gel dengan basis HPMC memiliki kestabilan yang paling optimal dibanding gel dengan basis karbopol (Nursiah et al., 2011). HPMC juga merupakan hidrogel yang baik karena HPMC mengambang terbatas dalam air (Voight, 1994).

Dalam pembuatan sediaan gel, banyak hal yang perlu diperhatikan antara lain stabilitas fisika-kimia komponen pembentuk gel, efek basis, proses pencampuran bahan dan lain-lain. Oleh karena itu, sediaan gel yang sudah jadi, perlu dievaluasi untuk mengetahui kestabilan gel tersebut, baik dari segi fisik maupun kimia. Konsentrasi ekstrak tanaman yang paling baik adalah 2,5\% dan konsentrasi HPMC untuk menghasilkan sediaan gel yang baik adalah di atas 3\% (Dass dan Vasudevan 2006; Maryawati, 2006).

Berdasarkan hal-hal tersebut, maka perlu dilakukan penelitian mengenai ekstrak etanol daun bidara dengan memformulasikannya dalam bentuk sediaan gel serta uji aktivitas antioksidannya. Sediaan gel lebih disukai pemakaiannya oleh masyarakat karena mudah dibersihkan dan nyaman pemakaiannya di kulit. Sediaan gel ini 
akan bermanfaat nantinya untuk kepentingan kosmetik yang fungsinya hampir sama dengan tabir surya.

\section{Metode Penelitian}

\section{Alat dan Bahan}

Daun bidara yang diperoleh dari kota Pekanbaru, Riau. Bahan lain yang digunakan antara lain etanol 96\%, air suling, HPMC, propilenglikol, metil paraben, propil paraben, dan DPPH sigma Aldrich untuk analisis antioksidan. Alat yang digunakan yaitu rotary evaporator, chamber, pengayak 40 mesh, timbangan analitik, dan spektrofotometer UV-Vis.

\section{Jalannya Penelitian}

1. Pembuatan ekstrak

$$
\text { Daun bidara yang sudah }
$$
dikeringkan, diserbuk, dan diayak menggunakan ayakan 40 mesh. Serbuk yang didapat kemudian diekstraksi dengan metode maserasi menggunakan pelarut etanol 96\%. Sebanyak 150 gram serbuk daun bidara direndam dengan pelarut etanol 96\% sebanyak $1500 \mathrm{~mL}$ dan diaduk menggunakan electric stirrer selam satu jam dengan kecepatan 120 rpm. Selanjutnya didiamkan selama 24 jam tanpa pengadukan pada suhu kamar. Hasil maserasi disaring dan maserat yang diperoleh dimasukkan ke dalam wadah terpisah dari residu. Residu dimaserasi dengan cara yang sama. Hasil keseluruhan maserasi dipekatkan menggunakan rotary evaporator (Umar et al., 2012).

2. Identifikasi ekstrak etanol daun bidara

Ekstrak etanol daun bidara diidentifikasi secara organoleptis untuk mengetahui karakterisasi esktrak tersebut. Selanjutnya dilakukan pengujian untuk mengetahui kandungan flavonoid dari ekstrak etanol daun bidara. Beberapa tetes larutan asam asetat 10\% ditambahkan ke dalam beberapa bagian ekstrak. Endapan kuning menandakan adanya flavonoid. Sebanyak 3 tetes ekstrak ditambahkan $\mathrm{FeCl}_{3}$ akan terbentuk warna orange yang menandakan adanya senyawa fenolik (Rajendra et al., 2011).

3. Pembuatan sediaan gel ekstrak daun bidara

Basis gel dibuat dengan variasi konsentrasi HPMC 3, 5, dan 7\% (Tabel 1).

Tabel 1. Formula sediaan gel antioksidan ekstrak daun bidara (Ardana et al., 2015)

\begin{tabular}{lccc}
\hline \multirow{2}{*}{ Formula Gel } & \multicolumn{3}{c}{ Konsentrasi Bahan dalam Formula Basis Gel (\%) } \\
\cline { 2 - 4 } & F1 & F2 & F3 \\
\hline HPMC & 3 & 5 & 7 \\
Propylen glikol & 15 & 15 & 15 \\
Metil paraben & 0,075 & 0,075 & 0,075 \\
Propil paraben & 0,025 & 0,025 & 0,025 \\
Ekstrak daun bidara & 2,5 & 2,5 & 2,5 \\
Akuades ad & 100 & 100 & 100 \\
\hline
\end{tabular}


HPMC dikembangkan dengan air suling selama kurang lebih 24 jam, ditambahkan metil paraben dan propil paraben sebagai pengawet yang telah dilarutkan dalam propilen glikol sebagai humektan, dan diaduk dengan bantuan stirrer kecepatan 4-6 rpm sampai homogen. Selanjutnya campuran tersebut ditambahkan ekstrak etanol daun bidara sebagai zat aktif antioksidan, kemudian ditambahkan lagi sisa propilen glikol dan ditambahkan air suling hingga volume $100 \mathrm{~mL}$.

4. Uji stabilitas gel ekstrak daun bidara

Evaluasi kestabilan gel dilakukan selama tiga minggu, dimana dalam satu minggu dilakukan 2 kali stabilitas dan disimpan pada suhu ruang. Stabilitas yang diuji yaitu organoleptis (bau, warna, dan konsentrasi), homogenitas, pengukuran viskositas, $\mathrm{pH}$, dan daya sebar.

Uji homogenitas dilakukan dengan mengoleskan gel pada kaca transparan. Jika tidak ada butiran kasar menandakan bahwa sediaan ge homogen (Garg et al., 2002).

Uji $\mathrm{pH}$ dilakukan dengan menggunakan $\mathrm{pH}$ meter. $\mathrm{Uji} \mathrm{pH}$ dilakukan untuk menguji tingkat keasaman sediaan gel agar menjamin sediaan gel tidak menyebabkan iritasi pada kulit (Garg et al., 2002).

Daya sebar diuji dengan menaruh sediaan gel sebanyak 0,5 gram pada kaca transparan, kemudian ditutupi dengan bagian lainnya dan digunakan pemberat di atasnya hingga bobot mencapai 125 gram. Daya sebar diukur diameternya setelah 1 menit (Garg et al., 2002).

Pengukuran viskositas dilakukan dengan menggunakan alat viscometer, sampel gel ditaruh pada viscometer hingga spindel terendam. Spindel diatur dengan kecepatan 50 rpm (Garg et al., 2002).

5. Uji aktivitas antioksidan gel ekstrak daun bidara (Puspita et al., 2012)

Aktivitas antioksidan diuji dengan metode DPPH. Sampel gel antioksidan ekstrak bidara dari tiga formula dilarutkan dalam pelarut etanol 96\% hingga diperoleh larutan sebanyak 1,5 mL. Larutan DPPH dibuat dengan cara menimbang serbuk DPPH sebanyak $4 \mathrm{mg}$ kemudian dilarutkan dalam labu takar dengan etanol hingga tanda batas.

Penentuan absorbansi blanko DPPH menggunakan larutan DPPH sebanyak $3 \mathrm{~mL}$, ditambahkan etanol 3 $\mathrm{mL}$, dihomogenkan dan diamati absorbansinya pada panjang gelombang $517 \mathrm{~nm}$ menggunakan spektrofotometri UV-Vis. Selanjutnya dilakukan pengukuran absorbansi \% inhibisi sampel gel.

6. Analisis data

Analisis data yang digunakan adalah dengan metode scoring untuk mengetahui formula gel yang paling stabil secara fisik. Analisis deskriptif kuantitatif digunakan untuk mengukur aktivitas antioksidan dari gel ekstrak etanol daun bidara dengan metode DPPH. 


\section{Hasil dan Pembahasan}

Pembuatan Ekstrak

Ekstrak daun bidara diperoleh sebanyak 34,3 gram dengan rendemen sebesar 22\%. Ekstrak diperoleh dengan metode maserasi untuk dapat mengekstrak simplisia yang mengandung zat aktif yang mudah larut dalam cairan penyari. Cairan penyari yang digunakan adalah etanol $96 \%$ dikarenakan etanol lebih selektif, sulit ditumbuhi kapang dan kuman, tidak beracun, dapat bercampur dengan air dalam segala perbandingan, memerlukan panas yang lebih sedikit untuk proses pemekatan dan zat pengganggu yang larut terbatas (Depkes, 1986).

Identifikasi Ekstrak Etanol Daun Bidara

Karakterisasi ekstrak etanol daun bidara dilakukan secara organoleptis untuk mendeskripsikan bentuk, warna, dan bau ekstrak. Karakterisasi ini dilakukan sebagai tahap identifikasi awal yang sederhana (Tabel 2).

Tabel 2. Hasil karakterisasi ekstrak etanol daun bidara

\begin{tabular}{lc}
\hline Parameter & Hasil Karakterisasi Ekstrak \\
\hline Bentuk & Kental \\
Warna & Hijau kecoklatan \\
Bau & Khas bidara \\
\hline
\end{tabular}

Pada uji pendahuluan menggunakan beberapa tetes larutan asam asetat $10 \%$ ke dalam ekstrak etanol daun bidara, terbentuk endapan kuning yang menandakan adanya senyawa flavonoid pada ekstrak tersebut. Selanjutnya dengan penambahan beberapa tetes $\mathrm{FeCl}_{3}$ pada ekstrak terbentuk warna orange, sehingga ekstrak tersebut positif mengandung senyawa fenolik.

\section{Uji Stabilitas Gel Ekstrak Daun Bidara}

Uji stabilitas sediaan gel ekstrak daun bidara meliputi organoleptis, homogenitas, $\mathrm{pH}$, viskositas, daya sebar yang dilakukan selama tiga minggu, dimana dalam satu minggu dilakukan dua kali pengujian stabilitas dan disimpan pada suhu ruang. Hasil evaluasi dapat dilihat pada Tabel 3.

Tabel 3. Hasil evaluasi sediaan gel ekstrak etanol daun bidara selama 3 minggu

\begin{tabular}{lccccc}
\hline Sifat Fisik & Bentuk dan Bau & Warna & pH & Viskositas (cPs) & Daya Sebar (cm) \\
\hline F1 & Stabil & Coklat & 6,2 & 4300 & 3,6 \\
F2 & Stabil & Kecoklatan & 6,3 & 4000 & 3,0 \\
F3 & Kurang Stabil & Kecoklatan & 7,5 & 3800 & 2,8 \\
\hline
\end{tabular}


Dari data pada Tabel 3 dapat dilihat adanya perbedaan sifat fisik dari ketiga formula. F1 dan F2 dengan konsentrasi HPMC 3 dan $5 \%$ menunjukkan nilai $\mathrm{pH}$, viskositas, dan daya sebar yang lebih baik dibanding dengan F3. pH F1 dan F2 berada pada rentang $\mathrm{pH}$ kulit 4,2-6,5 sehingga dapat disimpulkan bahwa gel yang dibuat tidak akan mengiritasi kulit dan memenuhi persyaratan parameter sifat fisik dan stabilitas fisik gel yang baik. Hasil pengukuran viskositas pada $F 1, F 2$, dan F3 selama tiga minggu menunjukkan gel yang semakin kental. Hal ini disebabkan bahwa gel ekstrak dalam fase stabil. Selain itu juga membuktikan bahwa gel ini memiliki sifat tiksotropik yang merupakan salah satu syarat gel dermatologikal, yang artinya dapat membentuk semipadat jika dibiarkan dan menjadi cair pada pengadukan. Semakin meningkatnya viskositas, ikatan komponen dalam gel akan semakin kuat, sehingga dapat meminimalkan ketidakstabilan fase gel.

Uji Aktivitas Antioksidan Gel Ekstrak Etanol Daun Bidara

Hasil uji aktivitas antioksidan gel ekstrak etanol daun bidara dapat dilihat pada Tabel 4. Uji ini dilakukan untuk mengetahui seberapa besar aktivitas antioksidan yang dihasilkan dari gel ekstrak etanol daun bidara. Aktivitas antioksidan diuji menggunakan metode DPPH karena merupakan metode yang sederhana, murah, cepat, dan peka serta membutuhkan sedikit sampel. Pada metode ini senyawa antioksidan (yang ada pada ekstrak etanol daun bidara) akan bereaksi dengan radikal bebas DPPH melalui mekanisme donasi atom hidrogen dan menyebabkan terjadinya peluruhan warna DPPH dari ungu menjadi kuning.

Tabel 4. Hasil uji aktivitas antioksidan gel ekstrak etanol daun bidara

\begin{tabular}{ccc}
\hline Sampel & Absorbansi & \%Inhibisi \\
\hline DPPH & 0,824 & Kontrol \\
F1 & 0,391 & 52,55 \\
F2 & 0,423 & 48,66 \\
F3 & 0,553 & 32,88 \\
\hline
\end{tabular}

Dari hasil pengukuran panjang gelombang maksimum diperoleh nilai $517 \mathrm{~nm}$ dengan absorbansi 0,824. Selanjutnya dilakukan pengukuran untuk gel ekstrak etanol daun bidara. Hasil pengujian menunjukkan bahwa larutan uji yang ditambahkan DPPH menghasilkan absorban hitung, artinya sediaan gel mampu meredam DPPH yang merupakan radikal bebas. Dari hasil absorbansi yang didapat kemudian dihitung persen inhibisi DPPH, yang menunjukkan besarnya aktivitas antioksidan larutan uji gel ekstrak etanol 
daun bidara terhadap radikal bebas (DPPH). Dari Tabel 4, dapat dilihat persen inhibisi pada 3 formula gel ekstrak etanol daun bidara yaitu 52,55 ; 48,66; dan 32,88\%. Berdasarkan literatur kategori antioksidan, F2 dan F3 merupakan antioksidan yang tidak aktif karena persen inhibisinya kurang dari $50 \%$, sedagkan F1 termasuk kategori sedang karena persen inhibisinya berada pada rentang 50\%-80\%. Kategori antioksidan aktif adalah di atas $80 \%$ (Molyneux, 2004).

\section{Simpulan}

Gel ekstrak etanol daun bidara memiliki aktivitas antioksidan yang berbedabeda berdasarkan variasi konsentrasi HPMC. Peningkatan konsentrasi HPMC menyebabkan perbedaan kemampuan pelepasan zat aktif yang ditunjukkan dengan persen inhibisi yang berbeda yaitu $\mathrm{F} 1=$ $52,55 \%$, F2=48,66\%, dan F3=32,88\%.

\section{Ucapan Terima Kasih}

Penulis mengucapkan terimakasih kepada Direktorat Riset dan Pengabdian Masyarakat Direktorat Jenderal Penguatan Riset dan Pengembangan, Kementrian Riset, Teknologi, dan Pendidikan Tinggi melalui Hibah Penelitian Dosen Pemula Tahun 2019 dan kepada semua aspek yang terlibat pada proses penelitian ini.

\section{Daftar Pustaka}

Abalaka, M.E., Mann, A., Adeyemo, S.O. 2011. Studies on in-vitro antioxidant and free radical scavenging potential and phytochemical screening of leaves of Ziziphus mauritiana L . and Ziziphus spina-christi L . compared with ascorbic acid. Journal of Medical Genetics and Genomics, 3(2):28-34.

Ardana, M., Aeyni, V., Ibrahim, A. 2015. Formulasi dan optimasi basis gel HPMC (hidroxy propyl methyl cellulose) dengan berbagai variasi konsentrasi. Journal of Tropical Pharmacy and Chemistry, 3(2):101-108.

Ansel, H.C. 1989. Pengantar Bentuk Sediaan Farmasi. Edisi keempat. Jakarta: UI Press.

Dass dan Vasudevan, D.M. 2006. Effect of lechitin in the treatment of ethanol mediated free radical induced hepatotoxicity. Indian Journal Clinical Biochemical, 21(1):62-29.

Depkes. 1986. Farmakope Indonesia III. Jakarta: Depkes RI.

Depkes RI. 1995. Farmakope Indonesia IV. Jakarta: Depkes RI.

Garg, A., Aggarwal, D., Garg, S., Sigla, A. 2002. Spreading of semisolid formulation: an update. Pharmaceutical Technology, North America, 26(9):84-105.

Kaur, R., Kaur, U., Walia, H. Evaluation of free radical scavenging activities of aqueous extracts of fruits of Ziziphus mauritiana and Eriobotrya japonica through in vitro antioxidant assays. Global Journal of Research and Review, 2(1):30-36.

Molyneux, P. 2004. The Use of the stable 
free radical

diphenylpicrylhydrazyl (DPPH) for estimating antioxidant activity. Journal of Science and Technology, 26(2):211-219.

Nursiah, H., Faradiba, Baharuddin, G.A. 2011. Formulasi gel sari buah belimbing wuluh (Averrhoa bilimbi L.). Majalah Farmasi dan Farmakologi, 15(1):5-9.

Perumal, S., Mahmud, R., Piaru, S.P., Cai, L.W., Ramanathan, S. 2012. Potential antiradical activity and cytotoxicity assessment of Ziziphus mauritiana and Syzygium polyanthum. International Journal of Pharmacology, 8(6):535-541.

Puspita, E., Sulaeman. T., Kurniawan, D. 2012. Formulasi gel antioksidan dari ekstrak etanol bunga brokoli (Brassica oleracea L. var. italica) dengan menggunakan metochel K15 M premium EP. Pharmacy, 09(01):038-050.

Rajendra, C.E., Magadum, G.S., Nadaf, M.A., Yashoda, S.V., Manjula, M. 2011. Phytochemical screening of the rhizome of Kaempferia galanga. International Journal of Pharmacognosy and Phytochemical Research,
Rowe, R., Sheskey, P., Quinn, M.E. 2009. Handbook of Pharmaceutical Excipients. Edisi keenam. London: Pharmaceutical Press.

Samirana, P.O., Taradipta, I.D.M.R., Leliqia, N.P.E. 2018. Penentuan profil bioautografi dan aktivitas antioksidan ekstrak etanol daun bidara (Ziziphus mauritiana Auct. non Lamk.) dengan metode penangkapan radikal DPPH. Jurnal Farmasi Udayana, 6(2):1822.

Maryawati, A. 2006. Formulasi dan uji klinik gel antijerawat benzoil peroksida-HPMC. Skripsi. Fakultas Farmasi, Universitas Andalas.

Umar, M., Abdullah, M., Sadikun, A., Atangwho, I., Yam, M., Altaf, R., Ahmad, A. 2012. Bioactivityguided isolation of ethyl-pmethoxycinnamate, an antiinflammatory constituent, from Kaempferia galanga L. extracts. Molecules, 17(7):8720-8734.

Voight, R. 1994. Buku Pengantar Teknologi Farmasi. Diterjemahkan oleh Soendani, N. Yogyakarta: Universitas Gadjah Mada Press. 